\title{
EFFECT OF SOFT DRINK, ELECTRONIC MEDIA EXPOSURE, FAMILY INCOME, POCKET MONEY, AND NUTRITIONAL STATUS, ON AGE AT MENARCHE AMONG ADOLESCENTS IN SURAKARTA
}

\author{
Mirzawati Latifah ${ }^{1)}$, Bhisma Murti²), Yulia Lanti Retno Dewi3) \\ 1)Masters Program in Public Health, Sebelas Maret University \\ 2)Faculty of Public Health, Sebelas Maret University \\ 3)Department of Nutrition, Faculty of Medicine, Sebelas Maret University
}

\begin{abstract}
Background: Age at menarche has become earlier for the last 100 years. This situation poses worrying problem as it may be lead to an increased risk of premarital sex, teenage pregnancy, mental unpreparedness, and increased risk of malignant diseases such as ovarial cancer and breast cancer. This study aimed to determine the effect of soft drink, electronic media exposure, family income, pocket money, and nutritional status, on age at menarche among adolescents in Surakarta.

Subjects and Method: This was an analytic observational study with crosssectional design. The study was conducted in Surakarta, Central Java, from February to March, 2017. A sample of 100 female adolescents was selected by simple random sampling from several Junior High Schools in Surakarta. The exogenous variables were nutritional status, family income, and electronic media exposure. The endogenous variables were age at menarche, soft drink consumption, and pocket money. The data were collected by a set of questionnaire, and analyzed by path analysis.

Results: Age at menarche was affected by electronic media exposure $(b=-$ $0.65 ; \mathrm{SE}=0.25 ; \mathrm{p}=0.010)$, pocket money $(\mathrm{b}=-7.48 ; \mathrm{SE}=1.52, \mathrm{p}<0.001)$, soft drink $(b=-3.43 ; \mathrm{SE}=1.11 ; \mathrm{p}=0.002)$, and nutritional status $(\mathrm{b}=-1.31 ; \mathrm{SE}=-$ $0.59 ; \mathrm{p}=0.025)$. Nutritional status was affected by family income $(\mathrm{b}<0.01, \mathrm{SE}$ $<0.01, \mathrm{p}=0.323)$ and pocket money $(\mathrm{b}=0.24 ; \mathrm{SE}=0.29 ; \mathrm{p}=0.401)$. Electronic media exposure was affected by pocket money $(b=0.69 ; \mathrm{SE}=0.58 ; \mathrm{p}=0.234)$. Soft drink was affected by pocket money $(b=0.23 ; \mathrm{SE}=0.13 ; \mathrm{p}=0.074)$. Pocket money was affected by family income (b<0.01; $\mathrm{SE}<0.01 ; \mathrm{p}<0.001)$.

Conclusion: Age at menarche is directly affected by electronic media exposure, pocket money, soft drink, and nutritional status. Age at menarche is indirectly affected by family income, pocket money, and electronic media exposure.
\end{abstract}

Keywords: path analysis, menarche, soft drink, reproduction health

Correspondence: Mirzawati Latifah. Masters Program in Public Health, Sebelas Maret University, Jl. Ir. Sutami 36 A, Surakarta 57126, Central Java, Indonesia. Email: Mirzawati.Latifah@gmail.com. Mobile: +6282218490968. 